6. Філімонов В. І. Фізіологія людини : підручник / В. І. Філімонов. - Київ : ВСВ «Медицина», 2010. - 776 с.

\title{
References
}

1. Danylova N. N. Psykhofyzyolohyya : [ucheb. dlya vuzov] / N. N. Danylova. - M. : Aspekt-Press, 2000. -374 s.

2. Ilin E. P. Psihofiziologiya sostoyaniy cheloveka / E. P. Ilin. - SPb. : Pyter, 2005. - $412 \mathrm{~s}$.

3. Palmer Dzh. Эvolyutsyonnaya psykholohyya. Sekrety povedenyya Homo sapiens / Dzh. Palmer, L. Palmer. - SPb. : Praym - EVROZNAK, 2003. - 167 s.

4. Psykhofyzyolohyya : ucheb. dlya vuzov / pod. red. Yu. Y. Aleksandrova. - 3-e yzd., dop. y pererab. $-\mathrm{SPb}$. : Pyter, 2012. $-464 \mathrm{~s}$.

5. Svaab D. MY - эto nash mozh / D. Svaab. - SPb. : yzd. Yvana Lymbakha, 2014. $370 \mathrm{~s}$.

6. Filimonov V. I. Fiziolohiya lyudyny : pidruchnyk / V. I. Filimonov. - Kyiv : VSV «Medytsyna», 2010. - $776 \mathrm{~s}$.

I.M. Hrytsiuk, I. Sydoruk. THEORETICAL AND METHODOLOGICAL PRECONDITIONS OF NEUROTHEOLOGY: PECULIARITIES OF BRAIN AND BEHAVIOR OF RELIGIOUS PERSON

The article analyzes the philosophical and religious concepts, such as religion, "religiousness", from the standpoints of neurotheology and psychophysiology. Religious consciousness is its essential feature; therefore a person can be directly defined as a being, which has a conscious inner connection with God. So a person is connected with religion, but determining the level, depth of this relationship is not an easy matter. Therefore, one should not look for the only, well-established answer about the nature of religion, because to find a definition which would be fitted to all beliefs is very difficult. And consequently, to give a universal definition of religion or religiousness, that would reveal its nature, diverse functionality and historical variability is impossible, although all religions (especially the dominant ones) have much in common. The main thing without what any religion could exist is the recognition (faith) of a peculiar superhuman reality (supernatural), about which, as was mentioned by the well-known British philosopher and cultural scientist K.G. Dawson, a person knows something and all own life is guided by this.

Given this, many researchers explain the religion, its nature and origin, proceeding primarily from the idea of God as "fundamental truth", "absolute subject" of religion. They state that religion has arisen and exists only because there is God and there is a person, who is able to accept it under certain conditions. O. Men', one of the prominent Orthodox theologians, grounding the supernatural essence of religion, emphasized that religion is the human answer to the manifestation of God's essence in a person. In our theoretical research we sought to demonstrate the scientific psychophysiological approach to understanding this phenomenon. Such modern scholars as D. Swaab, R. Furman, A. Newberg, M. Persinger and many others, using the latest methods of psychophysiological research in their works, state that this is the peculiarity of a human brain certain structures' activity, its functional determinant.

Keywords: neuroevolution of a human brain, neurotheology, social psychophysiology, religiousness, religious behavior, psyche, brain development and learning.

УДК 159.98:37.013.77

М. І. ЗАМЕЛЮК, Л. І. МАГДИСЮК, Н. В. ОЛЬХОВА

\section{АРТ-ТЕРАПІЯ ЯК ЗАСІБ ТВОРЧОЇ САМОРЕАЛІЗАЦІЇ ОСОБИСТОСТІ}

У статті розкрито сутність творчої особистості майбутнього педагога, практичного психолога, завдання $i$ функціональні можливості арт-терапї, з'ясовано особливості ї̈ використання в умовах сучасних закладах освіти Украйни. 3'ясовано, щуо прочес навчання студентів основам арт-терапії створює єдиний арт-терапевтичний та 
освітній простір, щзо забезпечується системою «викладач-студент», допомагає у професійному становленні та особистісному зростанні майбутніх педагогів, практичних психологів. Окреслено тендениії впровадження арт-технології казкотерапї як методу, в якому казкова форма застосовується для інтеграчії особистості, розвитку ії творчих здібностей, удосконалення взаємодії з навколишнім світом. Охарактеризовано види казок та специфіку їх застосування у творчій самореалізаиії особистості.

Ключові слова: творчість, особистість, арт-терапія, арт-технологї, креативність, казкотерапія, види казок, творча діяльність, корекиія.

В статье раскрыта сущность личности будущего педагога, психолога, задачи и функциональные возможности арт-терапии, выяснены особенности ее использования в условиях современных учебных заведениях Украины. Установлено, что процесс обучения студентов основам арт-терапии создает единственное арт-терапевтическое $u$ образовательное пространство, что обеспечивается системой «преподаватель-студент», помогает в профессиональном становлении и личностном росте будущих педагогов, практических психологов. Определены тенденции внедрения арт-технологии сказкотерапии как метода, в котором сказочная форма применяется для интеграции личности, развития ее творческих способностей, совершенствование взаимодействия с окружающим миром. Охарактеризованы виды сказок и специфику их применения в творческой самореализации личности.

Ключевье слова: творчество, личность, арт-терапия, арт-технологии, креативность, сказкотерапия, виды сказок, творческая деятельность, коррекция.

Постановка проблеми. Стратегічна мета української освіти та суспільства - виявляти й підтримувати обдарування кожної особистості. Ця важлива робота покладається на кожного дорослого члена суспільства, але, передусім, на викладацьку громаду. Саме від викладача, педагога та психолога очікується кваліфікована діяльність із розвитку обдарованості особистості, що ймовірно забезпечить успіх у цій справі.

Аналіз останніх досліджень і публікацій. Враховуючи практичну відсутність наукових праць, присвячених вивченню арт-терапії як засобу творчої самореалізації особистості, предмет дослідження знаходиться у зоні дефіциту наукової рефлексії. Втім існує низка дослідників, практиків і теоретиків, які хоч і побічно, але допомагають його артикулювати: М. Андерсен-Уорен, І. Бреусенко-Кузнецов, О. Будза, М. Бурно, І. Вачков, О. Вознесенська, Ю. Гундертайло, Т. Зінкевич-Свстигнєєва, Т. Колошина, Е.Келліш, М. Кисельова, О. Копитін, Л. Лебедєва, А. Лоуен, Р. Мартін, В.Нікітін, Л. Мова, Є. Морозова, Л. Подкоритова, Н. Роджерс, К. Росс, О. Скнар, М. Сидоркіна, Ю. Соболев, Г. Ферс, Г. Хульбут [9].

Формулювання цілей статті. Проаналізувати арт-терапію як засіб творчої самореалізації особистості.

Виклад основного матеріалу дослідження. Викладач, педагогічний працівник, психолог, який безпосередньо працює $з$ потенційно обдарованими та талановитими дітьми, реалізуючи запити й потреби сучасного суспільства, має бути професійно і особистісно готовим до цілеспрямованого розвитку здібностей своїх вихованців. Відтак, він потребує постійного поглиблення, оновлення і розширення відповідних знань, відпрацювання умінь i навичок роботи 3 розвитку обдарованості дітей. Важливою сутнісною характеристикою викладача, педагога $\epsilon$ педагогічна культура, яка генетично пов'язана 3 духовною i професійною культурою особистості. Сформованість педагогічної культури характеризує творчу особистість, що постійно розмірковує, мислить альтернативно, незадоволена одержаними здобутками, здійснює пошук причин тих чи інших явищ, володіє розвинутим прагненням до творення. Формування педагогічної культури означає розвиток у студентів самосвідомості, самостійності, незалежності суджень у поєднанні з повагою до поглядів інших людей, почуття самоповаги, здатності орієнтуватися у світі духовних цінностей, уміння приймати рішення і нести відповідальність за свої дії і вчинки [1]. У контексті 
фундаменталізації та гуманітаризації, які $є$ основними стратегічними напрямами ВНЗ, визначаються шляхи вдосконалення професійної підготовки, зокрема, формування спеціаліста як творчої особистості, що поєднує в собі високий професіоналізм із соціальнопсихологічними якостями гуманіста і патріота, здатного вирішувати науково-технічні i соціальні проблеми сучасності.

Натомість аналіз педагогічної практики засвідчує наявність у системі професійної підготовки низки проблем, які не задовільняють сучасні запити суспільства і держави щодо особистісно-професійного розвитку майбутнього педагога, психолога, серед яких, зокрема, виокремлюємо такі: відсутність цілісної системи формування творчої особистості майбутнього педагога, психолога здатного виявляти і розвивати здібності, обдарування дитини, застосовувати оригінальні, нестандартні розв'язки у ситуаціях повсякденної виховної взаємодії 3 дітьми, та недостатня розробленість комплексу теоретичних i технологічних (методичних) засад щодо ії забезпечення [7].

Творчість являє собою процес, зворотній соціалізації. Якщо у процесі соціалізації особистість вбирає у себе багатство світу культури і трансформує у власний світ, то у процесі своєї творчості вона реалізує особисті потенції такої сили і значення, що вони збагачують світ культури, впливають на розум, почуття та емоції інших людей [4]. Дослідники наукової, художньої та технічної творчості неодноразово зазначали, що творчо орієнтована особистість, стикаючись із певною проблемою, переживає якийсь внутрішній поштовх, мобілізацію не тільки інтелектуальних, а й біологічних ресурсів. Творче піднесення - це не просто раптове осяяння, а особливий спосіб самоорганізації особистості, для якої немає нічого важливішого за іiі творчість [4]. Творча діяльність - це синтезування сприйняття, відображення дійсності, плюс задум автора (втілення власного бачення, надання йому оригінальної інтерпретації), а також процес складної чуттєво-мисленнєвої переробки отриманого внаслідок активного відбору різноманітного матеріалу завершується виявом творчою особистістю самої себе через предметність. Без суб' єктивності процес відображення дійсності був би механічним копіюванням, простою репродукцією [3].

Важливим засобом підготовки майбутніх педагогів і психологів у освітніх навчальних закладах як творчих особистостей є арт-терапія. На сьогоднішній день арт-терапія є засобом вільного самовираження, вільного самопрояву й самопізнання. Вона не має меж і обмежень у застосуванні. Арт-терапевтична робота у більшості випадків викликає у людей позитивні емоції, допомагає долати апатію, безініціативність, формувати активну життєву позицію та позитивне світосприйняття, відзначається особливою «м'якістю» прийомів i психокорекційних впливів. Арт-терапевтичні технології є засобом переважно невербальних комунікацій, мають значною мірою «інсайт-орієнтований» характер, зумовлюють атмосферу довіри, розуміння до внутрішнього світу людини. Арт-терапевтичні методи застосовуються у єдності з традиційними методами і прийомами професійної підготовки студентів (лекції, доповіді, написання рефератів, диспути, конференції, написання сценаріїв та планів уроків (занять), ігри, моделювання педагогічних ситуацій тощо) [9].

Професійному становленні та особистісному зростанні майбутніх педагогів i психологів сприяє як процес навчання студентів основам арт-терапії, так і створення єдиного арт-терапевтичного та освітнього простору, що забезпечується системою «викладачстудент». У процесі арт-терапії художня творчість допомагає зрозуміти й оцінити власні почуття, спогади, образи майбутнього, знайти час для відновлення життєвих сил і спосіб спілкування із собою. Тому арт-терапія - це технології створення та використання різних творів мистецтва 3 метою передачі почуттів, емоцій та інших проявів психіки людини. Використання терапії творчістю у роботі з дітьми чи дорослими дає надзвичайні результати, адже процес творення (не за вимогою, не за зразком) завжди приносить радість, і це вже важливо не залежно від того, народжується ця радість у глибинах підсвідомості чи $\epsilon$ результатом розуміння можливості порозважатися чи навіть покепкувати [5].

Засоби художнього самовираження в процесі арт-терапії не тільки допомагають відновити психічне здоров'я, поліпшити самопочуття, але і розкривають творчий потенціал особистості, його креативність. Креативність в цьому випадку служить основою готовності 
особистості змінюватися, вміти знаходити нестандартні відповіді на складні завдання, не слідувати стереотипам, i, звичайно, креативна людина більш приваблива в спілкуванні. Використовуючи танець, малюнок, ліплення, музику, прозу, казку, поезію, театр, ми можемо пізнавати хвилюючі життєві переживання, почуття й фантазії. Власне мистецтво відкриває витоки натхнення, ініціює творче зростання людини і зцілює пї душевні рани [6]. Компонентами креативної особистості виступають: мотиваційний, інтелектуальний, емоційний та комунікативний компоненти. Для розвитку їх необхідно розширяти рольовий простір кожної особистості та включати його в різноманітні види діяльності, які забезпечують творчу самореалізацію та створюють досвід соціальних відносин [9].

Для розвитку креативної особистості в процесі отримання освіти науковці рекомендують:

- свідомо експериментувати 3 новими формами організації занять, здійснюючи пошук методів максималізації підтримки, яку члени колективу надають один одному в творчому плані;

- намагатися створити у колективі атмосферу взаємодії та взаємного стимулювання до висунення ідей;

- розширювати участь і підвищувати зацікавленість кожного члена колективу у творчому процесі;

- постійно підкреслювати важливість оригінальних рішень в будь-яких предметних галузях;

- використовувати повноцінні проекти та завдання для тренувальних завдань;

- створити атмосферу постійного пошуку та припливу проблем (завдань);

- знаходити можливість заохочення нових думок та ідей, конструктивної критики;

- позбавлятися стереотипів і позбавляти від них інших, позитивно реагувати на запропоновані ідеї;

- накопичувати ідеї, неприйняті для вирішення конкретної задачі (вони можуть знадобитися), пошук сфери застосування цих ідей;

- надавати максимальну свободу в процесі творчості;

- розробити разом з колективом рейтингову систему оцінювання творчого (та/або креативного) внеску, заслуг і кінцевих результатів;

- заохочувати аналіз успішного або неуспішного досвіду вирішення проблем;

- розвивати та заохочувати взаємодію між групами, які паралельно вирішують власні задачі та розробляють власні проекти;

- підтримувати та допомагати в розширенні інформаційно-комунікативних каналів для отримування необхідних даних і знань [9].

Л. Лєбєдєва зазначає можливість застосувати арт-терапію як технологію таким чином: у вигляді окремих прийомів, техніки, процедур в конкретних виховних справах (заходах) в період різних педагогічних практик; у літніх оздоровчих таборах (дозвілля дітей, різні форми виховної роботи); у роботі студентських клубів, молодіжних неформальних об'єднань тощо [6].

До арт-терапевтичних технологій, якими нині активно послуговуються психологи, педагоги і власне арт-терапевти, відносять наступні різновиди:

1. Анімаційну терапію, що являє собою сучасну технологію соціальної реабілітації 3 метою зміни поведінки, міжособистісних і колективних відносин. У процесі анімаційної терапії відбувається, з одного боку, «розблокування» громадських зв'язків і встановлення теплих, довірливих відносин, 3 іншого - навчання та оволодіння навиками позитивного мислення, естетики і поетики.

2. Арт-синтезтерапію - комплексний метод групової психотерапії, що використовує синтез мистецтв. Ця технологія розглядається як самостійний напрям в лікувальнокорекційній роботі, де володіння технічними прийомами різних видів мистецтва поєднується iз знаннями психопатології і підпорядковане психотерапії мистецтв, психопатології.

3. Бібліотерапію - технологію, в основі якої лежить лікування і виховання за допомогою книг, словом, книгою. Здійснюється вивчення особливостей читацького 
сприйняття під час хвороби і розробкою способів психологічної корекції за допомогою спеціально підібраної літератури.

4. Кінотерапію - один з напрямків арт-терапії. Фільм - це метафора, де можна побачити відображення життєвої ситуації. Щоб допомогти пацієнтові, сюжет фільму має бути схожим із життєвою ситуацією, в яку потрапила людина, і запропонувати вихід з неї.

5. Драматерапію - терапію засобами театру і акторської майстерності.

6. Ігротерапію - терапію через гру, ігрові ситуації.

7. Музикотерапію - використання музики як терапевтичного засобу.

8. Орігамі - створення фігур з паперу.

9. Пісочну терапію - лікування під час роботи пацієнта з піском.

10. Ізотерапію - використання прийомів графіки, живопису для лікування

11.Казкотерапію - програвання і аналіз казок. Це терапія середовищем, особливо казковою атмосферою, в якій можуть проявитися потенційні можливості особистості, може матеріалізуватись мрія [9].

Зокрема, казкотерапія - це напрямок арт-терапії. У різних контекстах, цей термін використовують по-різному. Казкотерапію використовують i у вихованні, освіті, тренінговому впливі, і як інструмент психотерапії. Це пов'язано з тим, що зміст казки сприймається відразу на двох рівнях - свідомому та підсвідомому. До казок у своїй роботі звертались відомі закордонні та вітчизняні психологи: Р. Азовцева, Е. Берн, Е. Гарднер, Т. Зінкевич-Свстигнєєва, Є. Лисіна, А. Менегетті, М. Осоріна, О. Петрова, Е. Фромм та інші [8]. А. Коблова розглядає цей термін з різних точок зору і на різних рівнях. По-перше, казкотерапія - це лікування казками, це відкриття тих знань, які живуть в душі і $є$ в даний момент психотерапевтичними, також це процес пошуку сенсу, розшифровки знань про світ і системи взаємовідносин в ньому. Казкотерапія - це процес екологічної освіти і виховання дитини, це терапія особливим казковим середовищем, в якій людина може реалізувати свою мрію [3]. Вона виділяе наступні форми роботи з казками:1) читання і аналіз казки; 2) розповідь казки; 3) створення казки; 4) переписування; 5) інсценування казки; 6) ілюстрування казки; 7) лялькотерапія [3]. Використання казок на заняттях спрямовано на підвищення ефективності діяльності людини. Широке застосування казок сприяє формуванню лінгвістичної компетенції у дітей та дорослих. Зміст текстів казок сприяе розширенню активного запасу слів, які вивчаються. Драматизація казок сприяє створенню психологічного комфорту. Казкотерапія - це метод, у якому казкова форма застосовується для інтеграції особистості, розвитку іiі творчих здібностей, удосконалення взаємодії 3 навколишнім світом. У процесі казкотерапії використовують різні жанри та види казок. Серед жанрів можна визначити: притчі, байки, легенди, міфи, билини, казки, анекдоти та інші [2]. Казки залежно від своєї мети можуть бути діагностичними, коригувальними і психотерапевтичними [3].

Діагностичні казки застосовуються на початковому етапі казкотерапії, оскільки дозволяють діагностувати, виявити певні властивості особистості, проблеми, рівень розвитку необхідних знань про навколишню дійсність, життєві цінності тощо. Після проведення діагностики використовуються казки, основною метою яких є корекиія, тобто розвиток необхідних навичок, умінь, набуття знань, що можуть допомогти людині надалі. За допомогою коригувальної дії виявляється вплив на поведінку людини, формується позитивний стиль поведінки. Після декількох сеансів казкотерапії дитина набуває упевненості в собі, їй легше спілкуватися з оточуючими [2].

Психотерапевтичні казки можуть застосовуватися як на завершальному етапі казкотерапії, так і на будь-якому іншому. Тобто вони можуть бути використані замість коригувальних або замість діагностичних. Основним завданням психотерапевтичних казок $\epsilon$ дія не безпосередньо на образ мислення людини або іiї поведінку, а на сферу іiі несвідомого, тобто на ії духовну складову. Вони не дають конкретних готових відповідей на запитання, що хвилюють людину, а дозволяють їй самій знайти їх [2]. Особливістю цього виду казок $\epsilon$ те, що вони здебільшого використовуються в роботі з дорослими, оскільки у дитини ще 
бракує знань, щоб самій знайти вихід із ситуації, що склалася, вона потребує допомоги i підтримки з боку дорослих.

Казки можуть класифікуватися залежно від того, ким вони написані. Існують авторські та народні казки. Авторські казки складають казкотерапевти, батьки або вихователі залежно від того, у чому необхідно допомогти дитині, які проблеми необхідно розв'язати, яких навичок набути. Народні казки - це казки різних народів світу, відомі всім із дитинства. Вони дуже важливі для дітей. Необхідно читати українські народні казки і казки інших народів, оскільки діти засвоюють із них не тільки моральні цінності, у них формується дружнє ставлення до інших народів, національностей. Важливим критерієм $\epsilon$ розподіл казок на індивідуальні та групові, спрямовані на дитячу аудиторію, підлітків і дорослих людей, які різняться своєю метою і проблемами, що порушуються в них. Так, наприклад, казки, що використовуються в роботі 3 підлітками, спрямовані на подолання комплексу неповноцінності, поліпшення взаємин з однолітками і батьками [2]. Казкотерапія для роботи 3 дітьми спрямована на подолання дитячих страхів, підвищення самооцінки, розвиток творчих здібностей, соціальної компетентності, моральних якостей тощо. Групова казкотерапія застосовується здебільшого в закладах дошкільної освіти і школах із дітьми дошкільного і молодшого шкільного віку. Група дітей повинна містити від 3 до 10 осіб. Чим більше дітей у групі, тим важче відстежити проблеми кожної дитини і подолати складнощі в інтерпретації казок. Діти цього віку орієнтуються на думку однолітків і схильні до впливу більшості. Отже, доцільніше проводити казкотерапію індивідуально або в невеликих групах [3]. Таким чином, казки необхідно підбирати залежно від мети, яку ставлять психолог, педагог і батьки; від ситуації, що склалася в житті дитини, іiі проблем, від бажаного результату процесу казкотерапії.

Висновки 3 даного дослідження і перспективи подальших розвідок. Арт-технології в педагогічному процесі - це сукупність психологічних методик впливу, що спираються на креативну (образотворчу і інші) діяльність особистості. Засоби художнього самовираження в процесі арт-терапії не тільки допомагають відновити психічне здоров'я, поліпшити самопочуття, розкривають творчий потенціал особистості, його креативність, синтезують візуальні знаки, створюючи художній образ дійсності. Казкотерапія - метод, що використовує казкову форму для інтеграції особистості, розвитку творчих здібностей, розширення свідомості, вдосконалення взаємодії з навколишнім світом.

Перспективами подальших розвідок у цьому напрямі $€$ авторська розробка ігор та апробація ігротерапевтичного методу з дітьми дошкільного віку, молодшими школярами 3 метою психокорекційного впливу на їхню емоційну сферу.

\section{Список використаних джерел}

1. Головей Л. А. Практикум по возрастной психологии : [учеб. пособ.] / под ред. : Л. А. Головей, Е. В. Рыбалко. - СПб. : Речь, 2002. - 694 с.

2. Зинкевич-Евстигнеева Т. Д. Путь к волшебству: (теория и практика сказкотерапии) : [книга для заботливых родителей, психологов, педагогов, дефектологов и методистов] / Т. Д. Зинкевич-Евстигнеева ; худож. Р. И. Шустров, ред. Г. А. Седова. - СПб. : Златоуст, 1998. - 349 с.

3. Исаева Н. Сказка как средство оптимизации психоэмоциональной сферы старших дошкольников / Н. Исаева // Дошкольное воспитание. - 2012. - № 7. - С. 19-24.

4. Кабачек О. Как страшное сделать нестрашным, или Зачем сочинять с детьми сказки / О. Кабачек // Домашняя школьная библиотека. - 2003. - № 3. - С. 34-36.

5. Колошина Т. Ю. Арт-терапия : метод. рек. / Т. Ю. Колошина. - М. : Изд-во Ин-та психотерапии и клин. психологии, 2002. - 84 с.

6. Лебедева Л. Д. Педагогические основы АРТ-терапии в образовании учителя : дис. ... д-ра пед. наук : 13.00.01 / Л. Д. Лебедева. - Ульяновск, 2001. - 383 с.

7. Ковальчук Л. І. Психодіагностика та психокорекція якості життя осіб з ургентною адикцією / Л.І.Ковальчук, Л. І. Магдисюк // Zbiór artykułów naukowych z Konferencji Miedzynarodowej NaukowoPraktycznej (on-line) zorganizowanej dla pracowników naukowych 
uczelni, jednostek naukowo-badawczych oraz badawczych z państw obszaru byłego Związku Radzieckiego oraz byłej Jugosławii. (30.11.2017). - Warszawa, 2017. - S. 66-68.

8. Румянцева Т. Н. Сказкотерапия как один из психолого-педагогических подходов по формированию основ этического поведения младшего школьника / Т. Н. Румянцева // Детство. Отрочество. Юность. - 2009. - № 3/4. - С. 64-104.

9. Смілянець I. О. Арт-терапія як засіб саморозвитку підлітків / I. О. Смілянець // Науковий огляд. - 2015. - № 2. - С. 42-45.

\section{References}

1. Gholovej L. A. Praktykum po vozrastnoj psykhologhyy : [ucheb. posob.] / pod red. : L. A. Gholovej, E. V. Rubalko. - SPb. : Rechj, 2002. - 694 s.

2. Zynkevych-Evstyghneeva T. D. Putj k volshebstvu: (teoryja y praktyka skazkoterapyy) : [knygha dlja zabotlyvыkh rodytelej, psykhologhov, pedaghoghov, defektologhov y metodystov] / T. D. Zynkevych-Evstyghneeva ; khudozh. R. Y. Shustrov, red. Gh. A. Sedova. - SPb. : Zlatoust, 1998. - $349 \mathrm{~s}$.

3. Ysaeva N. Skazka kak sredstvo optymyzacyy psykhoэmocyonaljnoj sferы starshykh doshkoljnykov / N. Ysaeva. // Doshkoljnoe vospytanye. - 2012. - № 7. - S. 19-24.

4. Kabachek O. Kak strashnoe sdelatj nestrashnыm, yly Zachem sochynjatj s detjmy skazky / O. Kabachek. // Domashnjaja shkoljnaja byblyoteka. - 2003. - № 3. - S. 34-36.

5. Koloshyna T. Ju. Art-terapyja. Metodycheskye rekomendacyy / T. Ju. Koloshyna. - M. : Yzd-vo Yn-ta psykhoterapyy y klyn. psykhologhyy, 2002. - 84 s.

6. Lebedeva L. D. Pedaghoghycheskye osnovы ART-terapyy v obrazovanyy uchytelja : dys. ... d-ra ped. nauk : 13.00.01 / L.D. Lebedeva. - Uljjanovsk, 2001. - 383 s.

7. Kovalzyk L. I. Psbxodiagnostika тa psixokorekzija jakosti zitta osib 3 urgentnoju adbkzijeju / L. I. Kovalzyk, L. I. Magdisyk // Zbiór artykułów naukowych z Konferencji Miedzynarodowej NaukowoPraktycznej (on-line) zorganizowanej dla pracowników naukowych uczelni, jednostek naukowo-badawczych oraz badawczych $\mathrm{z}$ państw obszaru byłego Związku Radzieckiego oraz byłej Jugosławii. (30.11.2017). - Warszawa, 2017. - S. 66-68.

8. Rumjanceva T. N. Skazkoterapyja kak odyn yz psykhologho-pedaghoghycheskykh podkhodov po formyrovanyju osnov эtycheskogho povedenyjamladshegho shkoljnyka / T. N. Rumjanceva // Detstvo. Otrochestvo. Junostj. - 2009. - № 3/4. - S. 64-104.

9. Smiljanecj I. O. Art-terapija jak zasib samorozvytku pidlitkiv / I. O. Smiljanecj // Naukovyj oghljad. - 2015. - № 2. - S. 42-45.

\section{I. Zamelyuk, L. I. Mandysiuk, N. V. Olkhova. ART THERAPY AS A TYPE OF CREATIVE SELF-REALIZATION OF THE PERSONALITYI}

In the article was highlighted the essence of the creative personality of a future teacher, a practical psychologist; tasks and functionality of art therapy and it was identified the peculiarities of its use in conditions of modern educational institutions in Ukraine. It was determined that the pedagogical direction of art therapy is an important aspect of creative self-realization of the personality, has a non-clinical orientation, designed for a potentially healthy personality, connected with the strengthening of physical and mental health of the child.

The attention is focused on art therapy which helps a person to return to the self-expression, self-discovery, self-creation, gives unforgettable impressions and feelings, activates the inner potential of the individual. It was found that the process of teaching students to the basics of art therapy creates a unique art-therapeutic and educational space, what is provided by the system "teacher-student", helps in the professional development and personal growth of future teachers, practical psychologists.

It was theoretically grounded: art-therapeutic work includes art-therapeutic technologies (animation therapy, synthesis therapy, bibliotherapy, fairy tale therapy, cinema therapy, drama therapy, game therapy, music therapy, origami, sand therapy, isotherapy), art-therapeutic methods (lectures, reports, writing essays, disputes, conferences, writing scripts and plans of lessons 
(classes), games, modeling of pedagogical situations, etc.). It was proved that spontaneity, creativity and creativity are the most important components of the art technology.

It was outlined trends in the introduction of art technology of fairy-tale therapy as a method in which a fairy-tale form is used for the integration of personality, the development of its creative abilities, and the improvement of interaction with the surrounding world. It was characterized the types of fairy tales, that are used in fairy tale therapy, with the respect to the specifics of their application in the creative self-realization of the personality.

Key words: art, personality, art therapy, art technology, creativity, fairy tale therapy, types of tales, creative activity, correction.

УДК 159.9:37.23

O. В. IBAHЮTA

\section{ДИНАМІКА ФОРМУВАННЯ ТА РОЗВИТКУ ОПЕРАЦІОНАЛЬНИХ ХАРАКТЕРИСТИК ВІЗУАЛЬНОГО МИСЛЕННЯ В ПІДЛІТКОВОМУ ВІЦІ}

У статті подано результати констатуючого експерименту, описано комплекс методів, які дозволяють діагностувати рівень розвитку операціональної сфери візуального мислення. Розглянуто динаміку формування та розвитку операціональних характеристик візуального мислення в підлітковому віці. Аналізуються міжструктурні зв'язки даних, отриманих за методикою Равена, що дозволяє зробити висновок про взаємозв'язок операціональних складових візуального мислення підлітків, щэо є надзвичайно важливим для розробки програми розвитку візуального мислення.

Ключові слова: візуальне мислення, операчіональна сфера візуального мислення, динаміка показників методики Равена, кореляційні зв'язки.

В статье представлень результаты констатирующего эксперимента, описано комплекс методов, позволяющих диагностировать уровень развития операчиональной сферы визуального мылиления. Рассмотрена динамика формирования и развития операциональных характеристик визуального мылиения в подростковом возрасте. Анализируются межструктурные связи данных, полученных по методике Равена, что позволяет сделать вывод о взаимосвязи операџиональных составляющих визуального мышления подростков, что является чрезвычайно важным для разработки программы развития визуального мышления.

Ключевые слова: визуальное мышление, операчиональная сфера визуального мышления, динамика показателей методики Равена, корреляционные связи.

Постановка проблеми. Необхідність впровадження нових ефективних технологій, які базуються на візуальних засобах кодування та передачі інформації, робить дослідження візуального мислення, а також пошук і розробку дійових засобів його розвитку одним із важливих завдань сучасної психологічної науки і педагогічної практики. Актуальність вивчення візуального мислення як специфічного виду розумової діяльності також визначається тим, що цей процес займає особливе місце в інтелектуальному і творчому розвитку особистості і $є$ найменш дослідженим з усіх інтелектуальних процесів як у вітчизняній, так і в зарубіжній педагогічній науці.

Аналіз останніх досліджень і публікацій. У вітчизняній психолого-педагогічній науці дослідження візуального мислення представлено: вивченням механізмів та закономірностей цього процесу в умовах вирішення ергономічних задач в інженерній психології (В. М. Гордон, В. ІІ .Зінченко, В. М. Муніпов); дослідженням його механізмів як складної функціональної системи операцій (Б. І. Безпалов); визначенням візуальної мови опису способів вирішення геометричних задач (І. М. Арієвич, В. В. Пєтухов); вивченням особливостей просторового мислення як окремого виду візуального мислення (I. Я. Каплунович [3], I. С. Якиманська); визначенням ролі візуалізації в процесі вирішення 